IJEBR

28,8

2000

Received 31 January 2021

Revised 16 April 2021

14 October 2021

Accepted 7 January 2022

\section{A digital business model: an illustrated framework from the cultural heritage business}

\author{
Tiziana Russo-Spena and Marco Tregua \\ Economics, Management, Institutions, University of Naples Federico II, Naples, Italy \\ Anna D'Auria \\ Human and Social Sciences, University of Naples L'Orientale, Naples, Italy, and \\ Francesco Bifulco \\ Humanities, University of Naples Federico II, Naples, Italy
}

\begin{abstract}
Purpose - The paper offers a comprehensive understanding of how digital transformation affects business models and how firms operate and compete effectively and successfully in a digital economy.

Design/methodology/approach - The research adopted an abductive approach (Dubois and Gadde, 2002) through constant movement between theory and empirical evidence. A systematic literature review led the first conceptual development and examples of practices from cultural heritage sectors were used in the theorizing process.

Findings - This paper depicts a digital model framework through a set of assumptions about how an organization creates and delivers value in an interconnected way by orchestrating new interactive processes, and providing experience propositions to customers, and about how value is framed in terms of economic, social and cultural outcomes.

Originality/value - The study contributes to the scientific debate by discussing the role of digital business models as enhancements more rather than replacements of traditional business models; it frames a digital business model as consisting of three main pillars: value orchestration, experience propositions and value sharing.

Keywords Business model, Cultural heritage, Digital transformation, Value orchestration,

Experience proposition, Shared value

Paper type Research paper
\end{abstract}

\section{Introduction}

Considerable research has been conducted on the "business model" in the age of digital transformation (Caputo et al., 2021; Russo-Spena et al., 2021). As technology evolves, both researchers and practitioners must deal with rapid changes in daily operations, and the development and restructuring of business models (Baden-Fuller and Haefliger, 2013; Langley et al., 2020). Business transformation involves new processes for integrating the growing body of digital technologies and the resulting customer, product and operational data (insights) into the organization to increase value creation capabilities (Basile and Faraci, 2015; Costa Climent and Haftor, 2021). Businesses are undertaking their own digital transformations, rethinking what customers value, and creating operating models that take

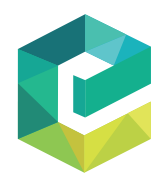

(C) Tiziana Russo-Spena, Marco Tregua, Anna D'Auria and Francesco Bifulco. Published by Emerald Publishing Limited. This article is published under the Creative Commons Attribution (CC BY 4.0) licence. Anyone may reproduce, distribute, translate and create derivative works of this article (for both commercial and non-commercial purposes), subject to full attribution to the original publication and authors. The full terms of this licence may be seen at http://creativecommons.org/licences/by/4.0/ legalcode

This paper forms part of a special section "Entrepreneurial development and digital transformation in creative and cultural industries: trends, opportunities and challenges”, guest edited by Antonio Lerro, Giovanni Schiuma and Francesco Manfredi. 
advantage of what is newly possible for business differentiation. A number of companies have built new forms of business models, based on an ecosystem that connects customers to a range of services, other customers, and/or other providers and actors ( $\mathrm{Ng}$ and Wakenshaw, 2017; Vargo and Lusch, 2017). Due to digital connectivity and network effects, formerly separate industries increasingly collaborate to offer new and better service provision. In some cases they conflate, contributing to the emergence of systems with a few players dominating a new digital hub economy (Iansiti and Lakhani, 2017). The emergence of these new relationships and business models has consequences for the entire market structure, the competitive forces within these "new markets" (including providers at different service network levels), and consumers and society ( $\mathrm{Ng}$ and Wakenshaw, 2017).

Some industries (e.g. the music business, the computer and software market, entertainment and e-commerce) are experiencing a far-reaching shift in their business models due to digitalisation (Li, 2020; Matzner et al., 2018; Ng and Wakenshaw, 2017). For example, cultural heritage and the services shaping the cultural industry have been affected by the advent of digital technologies, from basic issues, such as the introduction of websites, to more complex features shaping visitors' experiences (Amitrano et al., 2021; Raimo et al., 2021). Moreover, the recent COVID-19 crisis has accelerated digital transitions, especially of service-based industries, with the result that many organizations have been forced to move rapidly to a digital provision (Manser Payne et al., 2021); the cultural heritage sector is no exception (Network of European Museums Organization [NEMO], 2020a). Specifically, in the cultural heritage sector, the policy and practitioners debate started to recognise digital transformation as a main area of interest, based on the assumption that the notion of digital transformation demands higher-level socio-technical transitions that are beyond mere digitalisation of resources (NEMO, 2020a, b and c).

Notwithstanding this debate, the literature still lacks an organic contribution on how to address these points from a managerial point of view.

We find that the relationship between business models and technologies is essential for ensuring continuity in any business. The recent disruptive transformation in the cultural context provided by digitalisation requires a shift from technology-centric concerns to managerial and customer-centric concerns. Digital technologies have significantly accelerated experimentation with new opportunities for organizing cultural heritage activities (Jung et al., 2018; Lazzeretti and Sartori, 2016). Digital and new intelligent technologies are used to document, conserve, and communicate about cultural heritage; new smart devices and virtual reality are changing how heritage goods and services are modelled and delivered to create new visitor experiences that improve performance in cultural heritage sectors (Devine and Tarr, 2019; Keiningham et al., 2020). Similar to how technologies have changed actors' interactions, fruitful opportunities for cultural heritage industries have emerged, including those related to adoption and patterns of use, the effects of digital tools on communication, and how these tools may change business and market relationships (El Sawy and Pereira, 2013). However, current studies have not acknowledged how, as a whole, new digital technologies are affecting the architecture of the value creation, delivery and capture mechanisms (Teece, 2018) of cultural heritage organizations.

Furthermore, it is essential to understand how cultural heritage sectors can transform their business models to assess opportunities for technological change and achieve competitive advantage (Remane et al., 2017; Schiuma and Lerro, 2017; Verhoef and Bijmolt, 2019; Zott et al., 2011; Zhao et al., 2020). Our research question is: how are business models in the cultural heritage being transformed by digital technologies?

To address this gap, we adopted an abductive approach (Dubois and Gadde, 2002) through constant movement between theory and empirical evidence. A systematic literature review led to the first conceptual development and illustrations of practices from cultural heritage sectors were used in the theorizing process. 
IJEBR 28,8

This paper offers a comprehensive understanding of how digital transformation affects business models and how cultural heritage organizations handle business logic to compete more effectively in a digital economy. It contributes to the literature by framing a digital business model and illustrating its components using the cultural heritage sector as empirical evidence. It depicts a digital model framework through a set of assumptions about how an organization creates and delivers value in an interconnected way by orchestrating new interactive processes via digital technologies and providing experience propositions to customers, and about how value is framed in terms of economic, social, and cultural outcomes.

The paper makes three main contributions to the literature: first, it advances the debate about business logic in cultural heritage by adding new ideas, concepts, and tools that more deeply explicate the complex and multifaceted nature, structure and processes of doing business; second it presents new dimensions of digital business models that consist of value orchestration, experience propositions, and value sharing; third, it discusses the role of digital business models as enhancements more rather than replacements of traditional business models by advancing the understanding of the value dynamics of business models in an ecosystem view.

The remainder of this paper is structured as follows. First, it presents literature on digital business models and cultural heritage, after which it outlines the methodology and research process. Next, it presents the findings and empirically illustrates the key elements of the framework, with an empirical analysis in the domain of cultural heritage and, more specifically, in museums adopting digital technologies. Finally, it presents the main conclusion and discusses further research.

\section{Business models and the digital age}

In the last two decades, considerable research has focused on the "business model" which has led to multiple definitions that create significant challenges for understanding its essential components (Fritscher and Pigneur, 2011).

Most scholars discuss how a business model is a tool to describe how an organization creates, delivers, and captures value (Amit and Zott, 2020; Osterwalder and Pigneur, 2010; Teece, 2018). Other contributions depict the business model as representing a firm's strategy (Teece, 2010) with resulting terminological confusion because different concepts, such as business model, strategy, revenue model and economic model, are used interchangeably.

Many researchers proposed an understanding of digital transformation through the lens of specific business aspects or functions (Russo-Spena et al., 2021). For example, scholars have emphasized how technologies support new opportunities for digital offerings (Kopalle et al.,2020) or specific customers' experiences based on the omnichannel journey (Barwitz and Maas, 2018) and social media communication (Treem and Leonardi, 2013). Also, the focus is more on what Demil and Lecocq (2010) termed the "transformational approach," namely, a business model innovation based on initiatives that challenge existing industry-specific businesses and create new ones (Inigo et al., 2017).

With the advent of digital technologies, the network-level business models have become more relevant than solely firm-centric level ones (Adner, 2017; Bankvall et al., 2017; Oskam et al., 2018; Zott and Amit, 2017). Digital technologies have called into question the traditional way of doing business through collaboration, and the elements and relationships leveraged by firms to create appropriate value have been questioned. For example, some scholars have envisaged a new conception of the business model shaped through new technologies that improve stakeholders' management and relationships and generate more fruitful business collaborations to create and share value (El Sawy and Pereira, 2013). However, several studies 
are based on data from e-commerce or so-called platform firms (Zhao et al., 2020) from around the turn of the millennium.

While platform firms are gaining momentum, the development, adoption and use of various digital technologies due to the pandemic crisis have advanced well beyond early e-business or platform contexts (Zhao et al., 2020). In line with Iansiti and Lakhani (2014), scholars argued that digital transformation changes the customer's value proposition; it alters how a company creates and captures value because digitalisation principally involves the provision of services; opportunities to expand services increase when companies synchronize digitalisation, connectivity and data analytics (Gürdür et al., 2019). Most other scholars have described the business model as a set of interrelated activities that highlight its multi-sided or ecosystem nature (Parmentier and Gandia, 2017; Zhao et al., 2020). Digital business ecosystems allow capabilities to be combined across boundaries into innovative new offerings and solutions that create and capture value (Remane et al., 2017; Verhoef and Bijmolt, 2019). Digital transformation addresses the significant challenge of how firms can open up their business models (Bican and Brem, 2020; Frankenberger et al., 2014; Tesch and Brillinger, 2019). The reference unit concerning the level of collaboration and integration is primarily the customer, but a digital transformation also affects companies' partnerships at the industry and competitor levels.

New market opportunities have increased uncertainty, with special reference to the service sector, leading to the definition of disruptive digital-based business models (Bican and Brem, 2020; Teece, 2018; Verhoef and Bijmolt, 2019). Langley et al. (2020) showed the impacts of Internet of Everything on business models and highlighted the changes occurring at the business, industry and institutional levels. Moreover, they set a research agenda in the business domain to understand how digital technologies are changing business logic and society models.

Digital business models are useful for adapting the architecture of a firm's value proposition, market segments, value chain and value appropriation to emerging digital opportunities. In this sense, digitalisation, such as the use of digital technologies to change a business model, has been discussed more in terms of how to provide new or added revenue and value-producing opportunities (Osterwalder and Pigneur, 2010; Shafer et al., 2005; Veit et al., 2014). However, the transformation of the traditional business model into a digital business model requires more than delivering new or additional value to customers and the ability to compete effectively.

Indeed in the service context, customers and firms are expected to cooperate to achieve value creation (Kindström, 2010; Weill and Woerner, 2013). In the cultural heritage sector, recent researches underline that the digitalisation implies more than a change in offerings; it redefines the way organisations connect with the customers and their wider stakeholders (Schiuma and Lerro, 2017; Zott et al., 2011).

Digital technologies do not simply displace and replace existing digital components; they enhance and digitize them, turning them into data sources and enabling novel connections and recombinations (Iansiti and Lakhani, 2014) in a wider or interconnected context.

Recent studies addressed the ongoing changes in business model and called for further research, due to their focus on the transformation in traditional industry (Chen et al., 2021) or in geographical contexts wider than a country (Miroshnychenko et al., 2021). Digital business models must frame the complex and dynamic ecosystems of the company and its interactions (Kohtamäki et al., 2020). It is necessary to consider the implications of using technology within and across the organization, and to investigate how technology is connected to novel ways of conceptualizing value and its related processes from a wider perspective.

\section{Research process}

This research adopted an abductive approach (Dubois and Gadde, 2002) due to the emergence of novel elements in digital business models and the well-established literature on business 
IJEBR 28,8

models. Dubois and Gadde stressed the role of the literature review in identifying previous contributions and highlighting research gaps, and they recommended considering it in light of new phenomena to "confront theory with the empirical world" (p. 555). In the same vein, Teixeira de Melo (2020) focused on abductive research as a process to leverage openness and confront complexity. Similarly, Blaikie (2007) suggested an abductive approach in social sciences to interpret reality and contribute to theoretical development to clarify the meanings, interpretations, behaviour, and choices shaping daily life.

\subsection{Context of the study: cultural heritage}

We chose to look at cultural-heritage-related business practices for several reasons. First, scholarly contributions show that the digital transformation of cultural heritage is increasing in parallel with the improvement of the quality of technical equipment and digital tools, and that it creates and addresses customers' accurate reproductions of cultural artefacts and sites (Lazzeretti and Sartori, 2016). It is worth noting that cultural heritage businesses are particularly challenged by rapid changes in their activities and competitive context; likewise, several examples show that firms in this industry are far from reaching a standard in business models (Zhao et al., 2020). The cultural heritage industry requires a logic that embeds multiple aspects (Russo-Spena et al., 2017, Russo-Spena and Bifulco, 2021). Many organizations that are part of the cultural industry are still more "welfare-dependent" or "publicly funded" (and technologies represent new levers for incorporating a commercial logic and defining appropriate ways to compete in the new context.

Second, investments in digital technologies in cultural heritage entities have been encouraged and are still increasing. In 2014, a pool of experts, including Nick Poole - the chief executive of the Collections Trust, an organization operating with a network of 23,000 museums - and Kimmo Levä - the secretary general of the Finnish Museums Association suggested investing in new technologies to digitize all functions (NEMO, 2014). Similarly, the Museum Sector Alliance (Mu.Sa, 2017) invited museums to capture all the potentialities brought by new technology infrastructures, especially in countries with a digital divide in this sector (e.g. Italy, Greece, Bulgaria and Romania) due to a lack of investments. For example, the UK government planned to invest $£ 19$ million to increase the accessibility of Britain's cultural treasures, and NEMO (2020b) called for increased investment to adapt the offering to new conditions.

Third, digitalisation is meant to be a not-to-be-missed step in the management of museums; this idea was addressed in the Smithsonian Magazine in 2013 to stress the universality in the use of digital technology to innovate its offering and to let people share in museums' research (Stromberg, 2013). Similarly, NEMO (2020c) considered the obstacles to overcome in the digital transformation of museums and debated the significance of the implementation processes at the national level of the EU's Digital Single Market Directive.

Finally, looking at one type of business for technology applications allows methodological homogeneity, and it guarantees that analysis facilitates comparisons across studies and that the novel frameworks are more consistent (Patton, 2002; Ridder, 2017). Indeed, internal homogeneity is coupled with high detail in description, expanding the relationship between issues in a certain setting.

\subsection{Research phases}

We divided our research process into two phases: (1) a systematic literature review and (2) an empirical analysis.

3.2.1 Systematic literature review. Hammond and Wellington (2012) stressed the usefulness of a systematic literature review as a way to parallel theory and practice-based evidence. Such a review can synthesize the key elements and thoroughly understand what 
the observation of empirical-based contexts offers. Rather than forcing the ties between theory and practice, we repeatedly counter-checked to achieve a higher level of information completeness and credibility in results. Additionally, the systematic review provides a rigorous approach and outcomes, reduces bias and errors in the analysis, and maps a research area and data synthesis that integrate the most recent advances (Chen and Song, 2017). Moreover, a review is replicable and can favour future advances in research on the topic.

We performed the systematic review following the methodological suggestions of Kilubi and Haasis (2015) to review and combine insights from multiple authors. Thus, the first step was database selection. We chose Web of Science (WoS), which is used by scholars in business studies due to its broadness of research scope and is suitable both for qualitative approaches (e.g. Martineau and Pastoriza, 2016) and for quantitative studies (Cisneros et al., 2018). Next, we selected contributions based on their source (i.e. the journal) to meet the research goal. Papers were further selected by reading the abstract, leading to the fourth step: the classification of these contributions. The systematic review ended with the article analysis.

The first three steps sought to identify, select and provide a first view of the relevant documents. We searched for articles using two alternative queries on WoS: "digital business model*" and "business model*" + "digital*" in the field of science referred to as "Business and Management". The combination of the two outputs from WoS created a dataset consisting of 616 contributions from 2005 to 2021, with a very significant peak in 2021, besides the year is still in progress. We filtered the contributions according to the source, basing our choices on journal articles to focus only on peer-reviewed contributions. In total, 265 contributions were identified, with approximately a quarter of them being published in 2021.

To classify the articles, we defined a common research strategy to analyse the contributions based on the abstract, title, and keywords. First, we created a small sample of 10 papers, then we met online to exchange opinions on this first small dataset and to fine-tune the selection process (Light and Pillemer, 1984), to increase rigour, and to discuss potential disagreements. Three categories - namely, (1) totally relevant, (2) partially dealing with the topic and (3) not pertaining - were identified through a content analysis stemming from a meticulous reading of the abstracts. The 265 contributions were distributed among them, except for seven that were unavailable. Another meeting took place to compare ideas and evaluate the contributions whose categorization remained doubtful. The outcome was 239 contributions that we decided to analyse in detail.

After classification, we scanned the contributions listed in the category "totally relevant" articles (76) in detail. We highlighted the key elements most frequently emerging from the abstracts and the keywords of the contributions, such as the digital model definitions, features of business models, digital strategy, value proposition, digitalisation, value processes, and relationships and collaborations. In particular, we highlighted the correspondence of each article with the issues that our study addresses. The content analysis allowed us to systematize the data in a replicable way and to compare perspectives on the results and disagreements (Light and Pillemer, 1984). Hence, we analysed together the connection of each document with respect to the issues investigated, after which we compared our results.

Finally, we revised our results through an interpretive process of selective coding, as suggested by Creswell (2014) who stated that the sense-making of researchers is crucial in this step for providing the right interpretation of theoretical advances in the context of each contribution. Therefore, we constantly compared categories to understand the construction of interrelationships through which the concepts were organized. Drawing on the literature mainstream to see a business model as a set of elements and activities to create, deliver, and 
IJEBR 28,8 capture value (Teece, 2010), we depicted a digital business model framework. We discussed categories to obtain a consensus, performing this process repeatedly and starting with different steps of the data analysis each time to increase the credibility, reliability and validity of the findings (Denzin and Lincoln, 1998).

3.2.2 Empirical analysis. In addition to searching for theoretical material, we looked for data on suitable cases for study. We started with the official websites of the EU and NEMO, both of which have published reports on digitalisation in cultural heritage. Upon identifying the European countries already implementing successful digital transformation processes in museums, we selected representative examples. We extensively reviewed museums' websites and official internal documentation, including board and expert meeting memorandums. The museums we considered in our analysis are all based in countries partnering with the NEMO initiative, thus they all joined the digitalisation process for cultural heritage, either directly or indirectly due to their being part of a national association of cultural heritage sites members of NEMO. We created a list of the 39 countries partnering NEMO and selected multiple entries for each of them. Data collection from the official sources of museums or national associations took place until reaching saturation of the evidence; finally, the authors compared the insights acquired through the analysis of the documents and chose the most representative cases. An average of 8 museums reports per country was collected and the homogeneity of these sources was ensured according to two main criteria, namely the completeness of such documents - thus, we discarded posters, summaries, brochures - and the timeliness, since we only selected reports issued from 2018 on. As it regards the second part of the analysis we conducted email interviews with museum managers who agreed to participate; out of 12 managers we contacted, only 2 of them gave their availability to support this part of the analysis. The presentation of findings followed recommendations by Alvesson and Sköldberg (2017); thus. we used illustrations to create more understanding of the emerging interpretations of the themes and their links, according to the content of official reports and the interviews we performed after the first analysis. In line with the abductive process, we held empirically oriented discussions about the cases' potential, which provided first-hand experience of the phenomenon.

The choices regarding analysis allowed us to refine our theoretical thinking, which influenced the empirical investigation; this is the back-and-forth path characterizing abductive research (Dubois and Gadde, 2002) and enabling continuous (re)combination of theory and practice. These simultaneous reviews of and decisions concerning the conceptual literature and the cases led to a more detailed and refined framework.

The presentation of the findings focuses on illustrating the framework and its elements by using excerpts of cases to explicate their content (Wacker, 1998). More specifically, Wacker's (1998) research guidelines stress the appropriateness of illustrative cases to show the practice-based side of a study and further elaborate on the extant theoretical literature selected when adopting an abductive approach. Finally, we performed two fine-tuning interviews (Johnson, 1997): first, we discussed the theoretical framework with an expert cultural heritage manager to gather external feedback about weaknesses in the identification of patterns and categories; then we interviewed a project manager leading a project of digital transformation in and for a network of museums. These interviews were intended to doublecheck the content of the interpretation and to limit the bias of our perspective by reducing subjectivity due to bringing in the interpretation of other actors. These actors have different backgrounds: the first is fully immersed in a museum setting, and the second is temporarily engaged in tasks related to cultural heritage. Thus, to familiarize us with issues from both cultural heritage and management (McCracken, 1988), they were chosen based on their expertise, their previous understanding of the context, and a clarification of the research goals. 


\section{Framework}

Based on Teece (2018) and other scholars' (i.e. Zott and Amit, 2010) definitions, we developed a theoretical framework of how digital technologies affect business models. The proposed framework (see Table 1) has three core dimensions: (1) value orchestration; (2) experience propositions; and (3) value sharing. Altogether, the elements identify the content (the experience offering and how it connects the company to the market), the architecture (the resources, activities, and ecosystem that enable the offering), and the value sharing (capital and revenue) shaped by technology to uniquely create and sustain companies' value processes.

Specifically, the first category of value orchestration moves from the logic of value creation (Teece, 2018; Zott and Amit, 2010) towards a cooperative and combinative process that benefits from actors' efforts and resources to design activities to address service offerings. Digital technologies (Kindström, 2010) offer opportunities to catalyse resource combinations in innovative ways.

The second category of experience proposition moves from value delivery and value proposition (Osterwalder and Pigneur, 2010) towards an interactive process involving customers and combines the offline and the online experiences (Remane et al., 2017). Technology enables the experience proposition to perform profiling and to combine and share knowledge.

Finally, the third category of value sharing moves from value capture and its monetization (Baden-Fuller and Haefliger, 2013) to consider value outcomes from multiple perspectives (e.g. the social) and describes new ways to increase efficiency and revenue opportunities (Schaltegger et al., 2016). Technology enables firms to leverage natural, social, and economic capital.

\subsection{Strategy of value orchestration}

The strategy of value orchestration is a process firms perform to combine resources, capabilities and efforts in setting a value proposition. Digital technologies enable such processes by reshaping the business architecture (comprising a firm's and partner's resources), capabilities and activities to make and deliver the customer value proposition (Mikl et al., 2020).

The concept of orchestration refers to the importance of moving from simply considering collaboration with partners (often from a supply chain perspective) to identifying how to better integrate resources and competence from multiple sources through the opportunities of digital connectivity and ubiquity (Langley et al., 2020), thereby creating novelty and chances for enhanced performance. A complex ecosystem perspective of business models emerges through the business landscape and across industries, addressing new ways to create, deliver and capture value. A firm can leverage the new technologies as a collector and integrator of resources, capabilities and efforts involving a wider range of actors to create the applications, software platforms, tools, and services needed to create integrated solutions (Huikkola and Kohtamäki, 2020).

Ecosystem approaches are relevant to deal with fast-changing environments and update a firm's strategic process (D'Auria et al., 2017; Ruggieri et al., 2018), because the participation of a community of actors (e.g. users, providers, other firms) prompts the possibility to unlock new sources of value creation.

There are many reasons why an ecosystem-oriented approach is appropriate for orchestrating a process favouring new combinations of resources and actors. First, resource scarcity makes the ecosystem the pathway to overcoming resource gaps and limits to improvement (Shaw and Allen, 2018). Second, digitalisation of activities leads to a new approach that sets the right conditions for integrating actors and their strategy and for business model from cultural heritage

2007 


\section{IJEBR 28,8}

\section{Literature on traditional business models}

Value creation (Teece, 2018)

Business models are a set of activities combined to create value (Zott and Amit, 2010)

Design elements and themes as activities and sources for value creation (Zott and Amit, 2010)

Value delivery (Teece, 2018) Products, services and values shape value proposition in business models and their representation (Osterwalder and Pigneur, 2010)

Value proposition is what a firm offers to customers prior to the service provision occurring (LeroiWeldens et al., 2017)

Value capture (Teece, 2018) Benefits to customers and partners flowing back as revenue (Osterwalder and Pigneur, 2010)

Monetization as part of value capture (Baden-Fuller and Haefliger, 2013)
Table 1.

Setting a framework for digital business models
Literature on digital technologies and business models

Cooperation in service context for value creation (Kindström, 2010)

Capabilities combined in new offerings in digital business ecosystems (Remane et al., 2017)

Resources, capabilities, and activities are reshaped through digital technologies (Mikl et al., 2020)

Data and information shape a company's relations in the ecosystem of which it is part

Digital transformation changes customer value proposition (Iansiti and Lakhani, 2014)

In digital business models, the experience is the final essence of an interactive process between firm and customers (To et al., 2019) Consumers may be profiled via data, and data expand customer knowledge (An et al., 2018)

An omnichannel strategy embeds offline and online experience as both a challenge and an opportunity (Verhoef et al., 2015)

Digital business model may reduce the cost burden (Prem, 2015)

Digitalisation provides new or added revenue (Veit et al., 2014)

Digital technologies offer the opportunity to consider new sources of capital and sources of revenue (Breuer and Lüdeke-Freund, 2017) Digitalisation allows firms to leverage natural, social, and economic capital beyond its boundaries (Schaltegger et al., 2016)
Business

models' core dimensions

museum settings

Value

The Galicia Jewish

Museum (Poland) orchestration combined resources - e.g. photos, videos - from multiple sources via digital technologies to expand the Media Resource Centre and shape its offering The Acropolis Museum (Greece) launched a project to create new content from visits and digital-based events, enriching the collection

Belvedere Museum

(Austria) offers online services and a virtual walking tour, transforming the solo physical experience by combining the digital and physical

The National Museum in Warsaw (Poland) engaged people both as members of the board and as visitors, immersing people in the cultural digital realm Rijksmuseum

(Netherlands) implemented high-tech solutions to connect channels and transform customers' experience

Museum of Kiasma

(Finland) increased its revenue through content accessible via a website and app

Museum of Science of

Trento (Italy) is a place to which people belong, with sustainability intertwining science, society, and nature
Experience proposition

Value sharing

profiting from rapid technological innovation instead of being overwhelmed by it (Oughton et al., 2018). Finally, the notion of an ecosystem is strictly tied to digitalisation, as digitalisation reshapes ecosystems. Therefore, the context in which firms operate changes, 
bringing new interactions that cross firms' and networks' boundaries (Kohtamäki et al., 2020), leading to new business opportunities.

The Galicia Jewish Museum in Krakow (Poland) well illustrates such concepts. It hosts multi-service and multi-actor contexts. Photographers, movie makers, and international funds and trusts help shape the offering via local exhibitions (either permanent or temporary), travelling exhibitions, online exhibitions, education projects, online education and an online bookshop. The actors bring resources and create novel activities to deliver services both locally and online. The Media Resource Centre is constantly expanded online through global contributions and may also be experienced through the website.

In a digital context, data and information are gaining relevance in the relations between a company and its ecosystems (Kohtamäki et al., 2020), stimulating scholars in investigating the concept of data-driven delivery (Sjödin et al., 2021), as a way to perform operations via the novel opportunities brought by artificial intelligence and scale business models. This relevance is sometimes greater than that of the traditional key resources and activities themselves, because companies often pay more attention to data and content generation in their value orchestration processes, which paves the way to new service and value (Ghezzi and Cavallo, 2020). The arrangement and exploitation of a proper combination of information and data lead to a potentially successful response to customers' needs (Oughton et al., 2018). Information is at the core of what business models provide to perform activities, thereby supporting the shaping of value propositions (Cristofaro, 2020). Information and digital sources (data, information, insights, reviews, photos, blogs, etc.) can be seen as the translation of a resource (or an asset) into something that customers and other actors can use or work with to exploit and provide new resources for companies (Tom Dieck and Jung, 2017). Digital technologies favour the availability of resources via multiple sources (Amit and Han, 2017), and they enable novel resources by enhancing value creation dynamics.

In this sense, user-generated information provides an example of the additional resources that the interactions of digital technologies favour by multiplying opportunities for marketing activities and innovation (Musteen et al., 2018). Rather than looking for a default product or service, actors look for content: something they can personalize via digital technologies and that represents the "touchstone" of the effectiveness of a firm's offering (Benlian, 2015). Companies can leverage the insights of users and other actors and set strategies based on these new sources of information. Thus, content is the core of an iterative process in which it is offered as the outcome of a firm's planned offering, but it is continuously reshaped via combination with other resources. Information and content generation lead to reconsideration of activities in business models, as the participation of multiple actors in creating content may offer a new view of activities.

A good example of value orchestration based on data and content generation is the Acropolis Museum in Greece. Together with other museums in Athens, it participated in a National Ministry for Arts and Education project to leverage social networks and users to create new content. Beginning in 2013, the project created a repository of new resources comprising cultural and educational items. The repository was constantly enriched by visitors, student groups, participants in digital-based events, and other actors involved in games, the use of digital applications, and other activities. More than 300 new entries enriched the already impressive collection of cultural artefacts, providing a full showcase of the cultural and historical value of the Acropolis, as well as of other attractions.

\subsection{Strategy of experience proposition}

The strategy of experience proposition includes business model elements devoted to meeting customer needs based on a company's links to its customers, thereby improving the overall consumption experience (Keiningham et al., 2020). 
IJEBR 28,8

The experience proposition plays a central role in the business model, expanding what consumers can access and including every interaction between the customer and the company (Lanzolla and Markides, 2021). The value proposition itself offers something to consumers, even before service is offered (Leroi-Weldens et al., 2017; Pencarelli et al., 2017), due to the cognitive effect. Similarly, the long-term effects and memory of an offering may bring potential value to consumers; therefore, its consequences can be better represented regarding the notion of experience. The experience proposition represents a pivotal part of new business models. A digital business model has been proposed that recalls the experience as the final essence of the interactive process between a firm and a customer (To et al., 2019). The experience is both pivotal and complex due to the multiple elements affecting the interactions with customers. Business models' core offering is no longer properly represented by a product- or service-based value proposition; instead, the experience is more suitable for describing what is offered to consumers and how firms make offers to focus on multiple configurations and benefits, and within a wider time frame.

An interesting example is the Belvedere Museum in Vienna, which offers many online services, allowing visitors to combine the physical and virtual experiences through online collections and a virtual walking tour of the collection. The museum website presents pictures of the permanent collection, with the opportunity to download an app and enjoy an augmented reality experience from home. Furthermore, digital technologies improve the onsite experience, as visitors can interact with the art pieces through their mobile devices via an app. The aim is to create a full-on virtual experience and transform physical museums into spaces that embrace interaction, encourage participation and increase engagement. This creates an environment that appeals to new visitors and fosters a more compelling experience.

Moreover, the strategy of experience proposition prompts personalization and shifts the focus away from the customer and its segment to personas and crowd actors. The huge quantity of potentially available data enables companies to shape a fitting consumer profile by improving and extending their customer knowledge and analysis (An et al., 2018; Sivarajah et al., 2017). The persona is an example or archetype of a specific group and type of people (An et al., 2018). Information regarding the use or task the customer is trying to address, the people and information that influence his/her choices, the feelings he/she experiences, and his/her values and personality must be considered (Lee et al., 2020). Personas include real and relatable customers whom companies must humanize and connect with, rather than simple measures to seize opportunities (An et al., 2018). Personality is also relevant when discussing the concept of "crowd actor" (Bigham et al., 2015), namely, individuals who are in each other's presence through technologies and interact with each other to share common beliefs, concerns, and interests. Crowd-based initiatives allow companies to benefit from the various types of expertise and resources with which people are endowed (Cappa et al., 2020) and to conceive of the value experience as necessarily interconnected through the crowd contribution.

An example is the National Museum in Warsaw, which launched the Critical Museum project in line with the museum-as-forum perspective to enhance visitors' - and, more generally, citizens' - critical thinking and participation. According to Murawska-Muthesius and Piotrowski (2015), the museum-as-forum is meant to be a new dimension of the museum, but not the only one. The idea of the critical museum was put into practice in a project called Interventions, Mediators and Art Homo Erotica to show that everyone, both inside and outside the museum, could have been part of a board of trustees and, at the same time, part of the audience; in other words, an individual is "capable of taking a stance on the key issues in Polish or East European societies, [being] an active actor in a process of developing democracy" (MurawskaMuthesius and Piotrowski, 2015, p. 137). 
Finally, new digital technologies affect the distribution and choice of market channels. Companies compete in wider and multiple markets, connecting with customers who were previously out of reach or making business interactions more comfortable and widely available, with no space and time constraints (Jocevski et al., 2019). This change affects business models, as the business environment changes according to single or multiple channels, leading to an omnichannel or cross-channel strategy (Davis-Sramek et al., 2020).

An omnichannel strategy integrates the offline (or on-site) experience with the online one (Verhoef et al., 2015). This combination is both a challenge and an opportunity, as customers seek opportunities to be served as soon as possible and in the most comfortable way. The challenge depends on the intricacies of channels and touchpoints given the impact of interconnected devices, social media, and apps. Nowadays, it is common for consumers to acquire information about a product or service through one channel and then purchase it from another. For firms, it is no longer the time to deal with both online and offline touchpoints as distinctive modes, as it is very challenging for companies to separate on-site and online markets due to them being highly integrated. The omnichannel strategy provides more chances to personalize a customer journey and results in a strategy more prone to creating seamless and contextual experiences for customers by overcoming the atomistic paths of the multichannel approach (Verhoef and Bijmolt, 2019); an integrative approach to omnichannel strategy needs for alignment among business units to positively affect the customer journey and the service flow (e.g. Bijmolt et al., 2021).

An example is the Rijksmuseum Museum in the Netherlands, which uses technologies to augment and connect its channels. The museum invests in high-tech solutions for its website, which is the key source of visits to the museum. It aims to turn digital visits into visits to the museum. For the museum, a better-quality platform should increase the possibility of transforming virtual tours into other actions, like subscribing to the newsletter or purchasing a ticket or merchandise. The museum has also invested in social media training and security, stimulating both the staff and customers to start blogging on Twitter. Additionally, it has improved its email newsletter marketing as well as its customer relationships to do more with insights from customers and market.

\subsection{Strategy of value sharing}

As the previous subsection shows, the concept of the business model in the digital revolution decade is increasingly connected to the concepts of collaboration and network and is based on new forms of value conceptualization. In this context, the strategy of value sharing captures the need to address new forms of capital (financial, human, intellectual, relational, and social) and potential new revenue sources (sharing, peer-to-peer interactions, transparency, trust, and sustainability) (Breuer and Lüdeke-Freund, 2017) to cover the costs and externalities associated with other business model elements and to generate a surplus or value. This strategy looks beyond the traditional focus on firms and finance, encouraging value creation and distribution across the business and social contexts.

The traditional financial models based on economic indicators show less explicit power in the era of new revenue generation based on digitalisation. Furthermore, digitalisation is extended by the growth of concepts that encourage use of a service/product mainly for the time or purpose needed by the client $(\mathrm{Li}, 2020)$. Similarly, digitalisation improves the value capture process by improving internal processes for cost-efficiency and new management approaches.

An example is the Museum of Kiasma, part of the Finnish National Gallery. The museum increased its revenue by providing new digital offerings, such as images for research, reproduction, and commercial purposes. A subscription to services accessible through the website and app still represents its new revenue policy. The museum shares its collections 
IJEBR 28,8 more, and with fewer restrictions, to bring it to a wider audience. Its aim is not only to attract audiences but also to find the easiest way to share its collections and connect with other groups.

However, the value sharing strategy goes beyond what Baden-Fuller and Haefliger (2013) call monetization, because a key part of the value capture consists of new systems determining the timing of payment or methods for collecting or expanding revenues (e.g. free, freemium, subscription, work-for-hire). Value sharing relies on how companies capture economic value while maintaining or regenerating value for multiple actors. The valueshared perspective recognizes the need to consider the multi-sided outcomes of digital business models, with effects to be measured on and for the wider social and economic context (Pisano et al., 2016). In other words, any business (model) depends on diverse stakeholders who provide diverse forms of social and intellectual capital and are all partners for whom value is created, destroyed or even missed (Urbinati et al., 2019).

The concurrent goals from the social and the environmental goals further challenged firms in shaping their business models, as well as in determining how to implement more sustainable solutions. A new emerging field of research looks at sustainability-centred approach to the business model (Boons and Lüdeke-Freund, 2013; Bocken et al., 2014) as a way to address innovation for a shared value creation (Porter and Kramer, 2011). Digitalization leverages the firm's business interests to enhance value capture "while maintaining or regenerating natural, social, and economic capital beyond its organizational boundaries" (Schaltegger et al., 2016, p. 6); furthermore, companies implementing digital technologies in business models are expected to shape the potentiality of their offering to create economic, social, and environmental value (Hiteva and Foxon, 2021).

In this sense, shared value is, therefore, an instrumental approach that does not simply redefine or broaden the purpose of business in society to seek value-driven win-win situations. It emphasizes the "embeddedness" of a business model within wider ecosystems, from which it receives inputs and to which it provides outputs and outcomes.

In this sense, MUSE (Museum of Science of Trento in Italy) provides evidence of how a cultural organization can share more with the local and scientific citizens. The museum gives citizens a place to find scientific authority and expertise and, above all, a place to belong by becoming a part of their lives. This is how the social value and, specifically, the culturalscientific value of the museum enable communities to create new forms of value. MUSE promotes sustainability topics by intertwining science, society, nature, and art. Specifically, it provides a view of the cultural organization that includes institutional and educational outcomes in its strategy, which are seen as useful for generating new value for a territory. Museums serve their communities by working with outside organizations and collaborating with shared leadership networks and local stakeholders on wider sustainability themes.

\section{Discussion}

By combining systematic literature with the analysis of evidence from cultural heritage sectors this work provides a framework for addressing the new layer that digital transformation has added to how cultural heritage organisations conduct business. As a unit of analysis, the business model provides an ecosystem perspective on how companies create, deliver, and capture value (Remane et al., 2017). Digital transformation impacts all these processes by reshaping the architecture for processes, products, services and information flows, which involves considering the customer's new role in being engaged and satisfied, the roles of multiple actors in being involved, and the integrated benefits (Osterwalder and Pigneur, 2010; Veit et al., 2014).

Following Teece's (2018) well-known conceptualization and based on the selected constructs of Osterwalder and Pigneur (2010), we developed the digital business model 
framework by abstracting these constructs to the digital domain from an operational point of view (Basile and Faraci, 2015). Three core components emerged: (1) value orchestration; (2) experience propositions; and (3) value sharing. We identified the architecture, content, and value processes that combine to allow companies to compete uniquely in the digital era (see Figure 1).

In our view, value orchestration refers to the opportunity that digital technologies provide to engage multiple actors in integrating their resources (data and information) and capabilities for new content generation. These aspects represent the new engine of partnerships, based on resource integration rather than simply collaboration.

The increase in technologies' convergence provides very powerful opportunities for the creation of networks. The ongoing searching and involvement of new actors are necessary for acquiring new specializations and implementing solutions to extant ideas. Museums have to cooperate with universities, hi-tech firms, and local agencies, since they combine the resources and the efforts, leading to new services built on a set of actors. (Interview with project manager, 2 April 2021)

This process has much potential due to the features of digital technologies, such as their ubiquity, their embedded dematerialization, and the opportunity for collaboration (Langley et al., 2020). This concept is useful for describing the new shape of resources in firms' activities. Resources are no longer static or material; rather, they assume a metainformational nature that constantly refreshes them through the integration of multiple actors' resources (Veit et al., 2014):

The museum's business strategy is the result of a participatory effort, through which the many voices of the museum have been listened to and returned to the organization in the development of the overall strategic design. (Interview with cultural heritage manager, 23 March 2021)

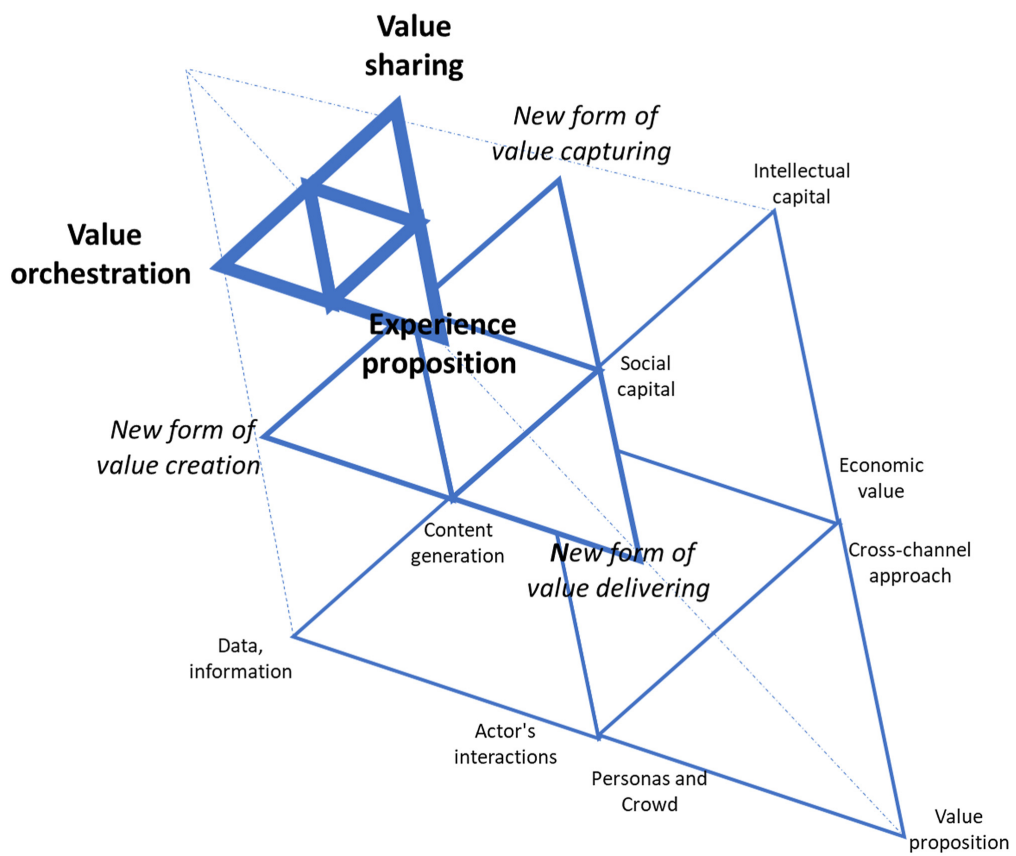

Figure 1.

Digital business models framework 
IJEBR 28,8

Thus, actors' resource integration, as well as data, information, and content generation, represent the cornerstone of how firms orchestrate the value creation infrastructure in order to compete. As the illustration shows, museums and cultural organizations have been the sectors hardest hit by pandemic-era social distancing measures. They must identify the advantages of unleashing the potential of new actors' resource combinations to overcome the limits they encounter in providing new or different offerings. The integration of actors' resources (including, for example, creative, customer, and local institutional resources) enabled by technologies favours the creation of novel resources leading to new ways to reconfigure activities and operative mechanisms based on new value proposals.

The most relevant and promising change is that digital technologies are reconfiguring the customer value proposition (i.e. what is being offered) and reshaping its delivery to create a seamless and immersive experience.

Special attention is paid to the seamless experience of the visitors, which supports and nurtures them along the entire visitor's journey in the awareness of the progressive affirmation of the BYOD [Bring Your Own Device] model. (Interview with cultural heritage manager, 23 March 2021)

What is really new is the unique experience each visitor can have, as the technological tools allow an integration of different channels (social network, chatbot, beacons, etc.) with personalization of the visits. (Interview with project manager, 2 April 2021)

Firms offer an experience proposition that mirrors the uniqueness and personalization of customer interactions with his/her context (Keiningham et al., 2020; Lanzolla and Markides, 2021). The specific and contextual customer preferences and requirements inform every market activity and optimize how data related to those specific contexts must be tracked and managed. The customer becomes a persona and lives a specific contextual and related dimension. In this sense, the consideration of crowds as the innate feature of new technologies provides more chances for interaction and participation, available content, experience, and new relations. As the illustrations show, COVID-19 has merely accelerated the need for museums to focus on the digital as part of their core value proposition strategy to enable creative, immersive, and interactive experiences that are highly personalized and socially engaging. However, museums' digital transformation does not involve simply considering how to digitize the offering, because easy transit must also be enabled among and between channels, both online and offline, in a wider collective dimension. It is not just a switch from a traditional channel to a new one; rather, it is a wide network of interactions and touchpoints in which the firm and the consumer are not the only entities. A multitude takes part in, and may affect, these processes (Kohtamäki et al., 2020).

New languages are needed that can help establish a bridge among different channels and with the new generations of communication tools (conversational agents, video games, films, photography, comics), constituting many sides of the same coin of a communication that must become more and more captivating. (Interview with cultural heritage manager, 23 March 2021)

Finally, the operating value model must be realigned to the new ecosystem and collective view so that it informs every activity in the value network (Kohtamäki et al., 2020; Ng and Wakenshaw, 2017). The many actors to consider can contribute to multiple, albeit different, ways of creating something of different value. New technologies enable companies to create and distribute value via economic and social capital, and not only for the customer. In this sense, value sharing is a new business logic that considers the multi-sided nature of value (economic, social, intellectual capital) to be created and distributed to the different actors (users, partners, community, etc.). Technologies support peer-to-peer interactions at the basis of sustainable network relationships that reinforce and support each other's actors (Kohtamäki et al., 2020). 
No museums are sufficiently sustainable on their own in terms of the financial means to improve their value proposition. Traditional and new activities converge thanks to innovative technologies, which help museums and stakeholders reap greater economic and social benefits from art and culture. A digital business model is not only a strategy for value creation of one museum, but a local and joined perspective and network engaging common stakes. (Interview with cultural heritage manager, 23 March 2021)

As the illustration shows, technology-enabled networks bring museums, visitors, users, creatives, and the community together in a social and collective capacity to be reinforced and empowered. Museums' social impact is not new (Pencarelli et al., 2017); what is new is the way this role can be addressed. Not only do technologies mediate in a network of interconnected objects, information, places, and people, but they also allow better transgression of the organizational boundaries towards an open and collaborative context where economic, social, and intellectual resources are created, shared, and distributed.

\subsection{Implications for scholars}

This paper makes three contributions to the literature on business models from a theoretical perspective.

This paper advances the debate on business logic in the cultural heritage sector (Schiuma and Lerro, 2017; Zott et al., 2011). Companies in this sector are still far from reaching a standard for business models (Zott et al., 2011). Our framework adds to scholars' efforts (Langley et al., 2020) to develop new ideas, concepts, and tools that more deeply illustrate the complex and multifaceted nature, structure and processes of cultural heritage business models. Supported by new technologies, cultural organizations can leverage the chances to create something new and valuable, and not only for visitors. This is not merely a switch from a traditional context to a digital one; rather, digital business models require new forms of creating cultural, social and economic value.

By assuming the perspective of cultural heritage evidence it contributes to the literature on business models concerning their digital based transformation. Recently, scholars have stressed the disruptive effect of these new technologies on business models (e.g. Teece, 2018), but a fresh understanding of how digital technologies permeate business models' essence is missing. This paper offers a new perspective on digital technologies' effect on business models by proposing three core components - value orchestration, experience proposition and value sharing - as the changes that impact traditional views. We recognize the technologies affecting value dynamics in business models (as in Bican and Brem, 2020; Teece, 2018). Our paper contributes by considering value as something depending on a set of metainformational resources and actors to be orchestrated, an experience whose value emerges via digital technologies and actors' individual efforts and preferences, and a value outcome that combines multiple sides.

In addition, this paper aligns with Iansiti and Lakhani (2014) conceptualization of digital business models as enhancements rather than replacements of traditional business models. The novel elements significantly change the value perspectives and what they consist of. Indeed, value orchestration leans on digital technologies to increase opportunities to combine resources, content and data as the not-to-be-missed elements that prepare the ground for experiencing value. In this way, we agree with the openness of business models as proposed by Frankenberger $e$ t al. (2014) and show how this opening leads to novel ways to shape data and, thus, content via orchestration of a digital context. Consequently, the experience is more prone to satisfying each customer in the way he/she prefers, due to opportunities to immerse customers in, and allow them to shape the experience. Thus, the value proposition recalled by Iansiti and Lakhani (2014) and the need for cooperation noted by Weill and Woerner (2013) 
IJEBR 28,8

should be seen via the opportunities offered by digital technologies. The integration of actors, content, and value orientations affects the business model structure due to the opportunities that digital technologies bring, with the result that business logics change. Therefore, we have answered Langley et al.'s (2020) call for research and expanded Prem's (2015) understanding of value dynamics.

The infusion of digital technologies leads to an ecosystem-based view of business models, because interactions may occur in multiple ways and in a wider context than those that a firm may decide to shape. Ecosystems are the context that shapes value logics both as a setting for enhanced opportunities and as a way to combine multiple views on value. These views are intertwined, expanding the logic of value capture that has traditionally shaped the extant contributions on business models (e.g. Remane et al., 2017; Teece, 2018), and allowing changes in markets and societies.

\subsection{Implications for practitioners}

The framework's aforementioned elements represent points on which to build a managerial approach able to support practitioners in implementing new strategies to compete in the digital era.

First, cultural organizations must address technologies not as add-on features of their strategies. They must regard digital strategies as integral to their decision-making and operative processes in order to anchor all their activities and digital assets on a long-term, sustainable basis. New technologies should be integrated into traditional ways of serving and engaging customers and other actors and involving those customers and actors to create and share economic and social value. This is particularly true in museums, which offer content based on authenticity and identity; both of which may be put at risk by the introduction of digital solutions. Museums represent local identity, and new technologies and digital devices need to be adopted with a view to establishing a bridge with the community. This suggests that companies must access the new competence that is integral to the different processes. New skills must cover various activities required to implement digital technologies and combine them with existing ones. Thus, cultural managers should verify if firms have suitable conditions for implementing these technologies or the intention to hire staff with the right skills to manage the digital transformation. This can be a challenge for museums as their workforces are typically small and have backgrounds in the arts and heritage. There is still a very strong digital competence gap within many museums, requiring much more investments in human capital. The acquisition of new interdisciplinary competences and the combination of various skills is an additional aspect that museums and cultural heritage organizations need to manage.

In addition, a solid omnichannel strategy needs to be framed to avoid conflictual conditions and overlaps between physical and virtual touchpoints, thus the virtual experience should be managed in a way that will not jeopardize the on-site visit. Managers and curators need to integrate an all-embedding virtual experience where museums connect with their visitors outside their building with physical experience to augment and complement each other to improve visitor engagement.

Cultural organisations also need a harmonized legal, technological, and institutional framework to operate across physical borders. For example, a new legal framework regarding intellectual property rights must make museums fully visible on the internet and provide the best access to and sharing of collections online. On the other hand, harmonization includes consideration of the institutions, particularly of the values and norms that lead customers and other actors to behave in a certain way and to adopt new technologies in their interactions and experiences. In museums, this can be particularly challenging, as they need to find a balance between tradition and modernity (and digitalization) that is acceptable to customers and the local community. 
In this sense, some policy implications also arise. The government-at both local, national, and supranational levels-needs to better support educational programs for reskilling and upskilling human resources and enhance collaboration, especially among small museums, to join their effort to design a more integrated visitor journey enabling a rich and engaging experience. Finally, the government needs to better recognize the social role of museums in society and support the creative wave that digitalization can unlock to encourage cultural heritage service innovations that can potentially transform and improve the lives of communities.

\subsection{Limitations and further research}

The main limitation of this study is that the application of the above-described techniques is still rare, despite being a relevant topic within scientific debates.

The illustrations provide interesting insights fine-tuned through interviews. Additional data once these new technologies are implemented may support further understanding of this topic. Therefore, additional interviews with museum managers, together with field analysis, are recommended to verify what the new technology-driven elements can offer. This evidence should be completed with analysis of the wider context in which services are offered and value forms part of the experience. Understanding these contexts may expand the understanding of business models in the cultural heritage sectors, so future research on contexts other than museums (e.g. education, entertainment) is encouraged.

Therefore, to extend and strengthen the findings of this paper, future research should more directly involve different actors and institutions (e.g. public or local institutions, community, users, providers of technology) and adopt active research methods (e.g. focus groups, action research) to understand such actors' and institutions' perspective on implementing a business model based on digital tools and new technology. It would also be useful to observe the concept of the ecosystem through different perspectives that combine firms' vision with that of companies, actors, and customers.

Finally, further studies on how social, cultural and environmental value can be proposed, created and shared through the business model are needed to improve the theoretical debate and, consequently, firms' practices.

\section{References}

Adner, R. (2017), "Ecosystem as structure: an actionable construct for strategy", Journal of Management, Vol. 43 No. 1, pp. 39-58.

Alvesson, M. and Sköldberg, K. (2017), Reflexive Methodology: New Vistas for Qualitative Research, Sage, Thousand Oaks, CA.

Amit, R. and Han, X. (2017), "Value creation through novel resource configurations in a digitally enabled world", Strategic Entrepreneurship Journal, Vol. 11 No. 3, pp. 228-242.

Amit, R. and Zott, C. (2020), Business Model Innovation Strategy: Transformational Concepts and Tools for Entrepreneurial Leaders, John Wiley \& Sons, Hoboken, NJ.

Amitrano, C.C., Russo-Spena, T. and Bifulco, F. (2021), "Digital engagement and customer experience", in Russo-Spena, T. and Bifulco, F. (Eds), Digital Transformation in the Cultural Heritage Sector: Challenges to Marketing in the New Digital Era, pp. 119-136.

An, J., Kwak, H., Jung, S.G., Salminen, J. and Jansen, B.J. (2018), “Customer segmentation using online platforms: isolating behavioral and demographic segments for persona creation via aggregated user data", Social Network Analysis and Mining, Vol. 8 No. 1, pp. 1-19.

Baden-Fuller, C. and Haefliger, S. (2013), "Business models and technological innovation”, Long Range Planning, Vol. 46 No. 2, pp. 419-426.

Bankvall, L., Dubois, A. and Lind, F. (2017), “Conceptualizing business models in industrial networks”, Industrial Marketing Management, Vol. 60 No. 1, pp. 196-203. 
IJEBR 28,8
Barwitz, N. and Maas, P. (2018), "Understanding the omnichannel customer journey: determinants of interaction choice", Journal of Interactive Marketing, Vol. 43 No. 1, pp. 116-133.

Basile, A. and Faraci, R. (2015), "Aligning management model and business model in the management innovation perspective: the role of managerial dynamic capabilities in the organizational change", Journal of Organizational Change Management, Vol. 28 No. 1, pp. 43-58.

Benlian, A. (2015), "Web personalization cues and their differential effects on user assessments of website value”, Journal of Management Information Systems, Vol. 32 No. 1, pp. 225-260.

Bican, P.M. and Brem, A. (2020), "Digital business model, digital transformation, digital entrepreneurship: is there a sustainable 'digital”, Sustainability, Vol. 12 No. 13, p. 5239.

Bigham, J.P., Lasecki, W.S. and Wobbrock, J. (2015), “Target acquisition and the crowd actor”, Human Computation, Vol. 1, pp. 101-131.

Bijmolt, T.H., Broekhuis, M., De Leeuw, S., Hirche, C., Rooderkerk, R.P., Sousa, R. and Zhu, S.X. (2021), "Challenges at the marketing-operations interface in omni-channel retail environments", Journal of Business Research, Vol. 122, pp. 864-874.

Blaikie, N. (2007), Approaches to Social Enquiry: Advancing Knowledge, Polity Press, Cambridge.

Bocken, N.M., Short, S.W., Rana, P. and Evans, S. (2014), "A literature and practice review to develop sustainable business model archetypes", Journal of Cleaner Production, Vol. 65, pp. 42-56.

Boons, F. and Lüdeke-Freund, F. (2013), "Business models for sustainable innovation: state-of-the-art and steps towards a research agenda", Journal of Cleaner Production, Vol. 45, pp. 9-19.

Breuer, H. and Lüdeke-Freund, F. (2017), "Values-based network and business model innovation", International Journal of Innovation Management, Vol. 21 No. 3, p. 1750028.

Cappa, F., Rosso, F. and Capaldo, A. (2020), "Visitor-sensing: involving the crowd in cultural heritage organizations", Sustainability, Vol. 12 No. 4, p. 1445.

Caputo, A., Pizzi, S., Pellegrini, M.M. and Dabić, M. (2021), "Digitalization and business models: where are we going? A science map of the field", Journal of Business Research, Vol. 123, pp. 489-501.

Chen, C. and Song, M. (2017), "Science mapping tools and applications", in Chen, C. and Song, M. (Eds), Representing Scientific Knowledge, Springer, Cham, pp. 57-137.

Chen, Y., Visnjic, I., Parida, V. and Zhang, Z. (2021), "On the road to digital servitization-The (dis) continuous interplay between business model and digital technology", International Journal of Operations and Production Management, Vol. 41 No. 5, pp. 694-722.

Cisneros, L., Ibanescu, M., Keen, C., Lobato-Calleros, O. and Niebla-Zatarain, J. (2018), "Bibliometric study of family business succession between 1939 and 2017: mapping and analyzing authors' networks", Scientometrics, Vol. 117 No. 2, pp. 919-951.

Costa Climent, R. and Haftor, D.M. (2021), "Value creation through the evolution of business model themes", Journal of Business Research, Vol. 122, pp. 353-361.

Creswell, J.W. (2014), A Concise Introduction to Mixed Methods Research, SAGE Publications, Thousand Oaks, CA.

Cristofaro, M. (2020), "E-business evolution: an analysis of mobile applications' business models", Technology Analysis and Strategic Management, Vol. 32 No. 1, pp. 88-103.

Davis-Sramek, B., Ishfaq, R., Gibson, B.J. and Defee, C. (2020), "Examining retail business model transformation: a longitudinal study of the transition to omnichannel order fulfillment", International Journal of Physical Distribution and Logistics Management, Vol. 50 No. 5, pp. 557-576.

Demil, B. and Lecocq, X. (2010), "Business model evolution: in search of dynamic consistency", Long Range Planning, Vol. 43 Nos 2-3, pp. 227-246.

Denzin, N.K. and Lincoln, Y.S. (1998), Strategies of Qualitative Inquiry, Sage Publications, Thousand Oaks, CA.

Devine, C. and Tarr, M. (2019), "The digital layer in the museum experience", in Giannini, T. and Bowen, J. (Eds), Museums and Digital Culture, Springer, Cham, pp. 295-307. 
Dubois, A. and Gadde, L.E. (2002), "Systematic combining: an abductive approach to case research", Journal of Business Research, Vol. 55 No. 7, pp. 553-560.

D’Auria, A., Tregua, M., Russo-Spena, T. and Bifulco, F. (2017), "Multiple context of innovation: insights from literature", International Journal of Innovation and Technology Management, Vol. 14 No. 2, p. 1740007.

El Sawy, O.A. and Pereira, F. (2013), Business Modelling in the Dynamic Digital Space: An Ecosystem Approach, Springer, Heidelberg.

Frankenberger, K., Weiblen, T. and Gassmann, O. (2014), "The antecedents of open business models: an exploratory study of incumbent firms", R\&D Management, Vol. 44 No. 2, pp. 173-188.

Fritscher, B. and Pigneur, Y. (2011), "Business IT alignment from business model to enterprise architecture", in Salinesi, C. and Pastor, O. (Eds), International Conference on Advanced Information Systems Engineering, Springer, Berlin, pp. 4-15.

Ghezzi, A. and Cavallo, A. (2020), "Agile business model innovation in digital entrepreneurship: lean startup approaches", Journal of Business Research, Vol. 110, pp. 519-537.

Gürdür, D., El-khoury, J. and Törngren, M. (2019), "Digitalizing Swedish industry: what is next? Data analytics readiness assessment of Swedish industry, according to survey results", Computers in Industry, Vol. 105, pp. 153-163.

Hammond, M. and Wellington, J. (2012), Research Methods: The Key Concepts, Routledge, Abingdon, Oxon.

Hiteva, R. and Foxon, T.J. (2021), "Beware the value gap: creating value for users and for the system through innovation in digital energy services business models", Technological Forecasting and Social Change, Vol. 166, p. 120525.

Huikkola, T. and Kohtamäki, M. (2020), "Agile new solution development in manufacturing companies”, Technology Innovation Management Review, Vol. 10 No. 3, pp. 16-23.

Iansiti, M. and Lakhani, K.R. (2014), "Digital ubiquity: how connections, sensors, and data are revolutionizing business", Harvard Business Review, Vol. 92 No. 11, pp. 19-28.

Iansiti, M. and Lakhani, K.R. (2017), "Managing our hub economy", Harvard Business Review, Vol. 95 No. 5, pp. 84-92.

Inigo, E.A., Albareda, L. and Ritala, P. (2017), "Business model innovation for sustainability: exploring evolutionary and radical approaches through dynamic capabilities", Industry and Innovation, Vol. 24 No. 5, pp. 515-542.

Jocevski, M., Arvidsson, N., Miragliotta, G., Ghezzi, A. and Mangiaracina, R. (2019), "Transitions towards omni-channel retailing strategies: a business model perspective", International Journal of Retail and Distribution Management, Vol. 47 No. 2, pp. 78-93.

Johnson, R.B. (1997), "Examining the validity structure of qualitative research", Education, Vol. 118 No. 2, pp. 282-292.

Jung, T.H., Lee, H., Chung, N. and Tom Dieck, M.C. (2018), "Cross-cultural differences in adopting mobile augmented reality at cultural heritage tourism sites", International Journal of Contemporary Hospitality Management, Vol. 30 No. 3, pp. 1621-1645.

Keiningham, T., Aksoy, L., Bruce, H.L., Cadet, F., Clennell, N., Hodgkinson, I.R. and Kearney, T. (2020), "Customer experience driven business model innovation", Journal of Business Research, Vol. 116, pp. 431-440.

Kilubi, I. and Haasis, H. (2015), "Supply chain risk management enablers - a framework development through systematic review of the literature from 2000 to 2015", International Journal of Business Science and Applied Management, Vol. 10 No. 1, pp. 35-54.

Kindström, D. (2010), "Towards a service-based business model-Key aspects for future competitive advantage", European Management Journal, Vol. 28 No. 6, pp. 479-490.

Kohtamäki, M., Parida, V., Patel, P.C. and Gebauer, H. (2020), "The relationship between digitalization and servitization: the role of servitization in capturing the financial potential of digitalization", Technological Forecasting and Social Change, Vol. 151, p. 119804. 
IJEBR 28,8

Kopalle, P.K., Kumar, V. and Subramaniam, M. (2020), "How legacy firms can embrace the digital ecosystem via digital customer orientation", Journal of the Academy of Marketing Science, Vol. 48 No. 1, pp. 114-131.

Langley, D.J., van Doorn, J., Ng, I.C., Stieglitz, S., Lazovik, A. and Boonstra, A. (2020), "The internet of everything: smart things and their impact on business models", Journal of Business Research, Vol. 122, pp. 853-863.

Lanzolla, G. and Markides, C. (2021), "A business model view of strategy", Journal of Management Studies, Vol. 58, pp. 540-553.

Lazzeretti, L. and Sartori, A. (2016), "Digitisation of cultural heritage and business model innovation: the case of the Uffizi Gallery in Florence", Il Capitale Culturale. Studies on the Value of Cultural Heritage, Vol. 14, pp. 945-970.

Lee, M., Kwahk, J., Han, S.H., Jeong, D., Park, K., Oh, S. and Chae, G. (2020), "Developing personas and use cases with user survey data: a study on the millennials' media usage", Journal of Retailing and Consumer Services, Vol. 54, p. 102051.

Leroi-Weldens, S., Sandra, S., Van Vaerenbergh, Y. and Grönroos, C. (2017), "Does communicating the customer's resource integrating role improve or diminish value proposition effectiveness?", Journal of Service Management, Vol. 28 No. 4, pp. 618-639.

Li, F. (2020), "The digital transformation of business models in the creative industries: a holistic framework and emerging trends", Technovation, Vol. 92, p. 102012.

Light, R.J. and Pillemer, D.B. (1984), Summing up: The Science of Reviewing Research, Harvard University Press, Cambridge, MA.

Manser Payne, E.H., Dahl, A.J. and Peltier, J. (2021), "Digital servitization value co-creation framework for AI services: a research agenda for digital transformation in financial service ecosystems", Journal of Research in Interactive Marketing, Vol. 15 No. 2, pp. 200-222.

Martineau, C. and Pastoriza, D. (2016), "International involvement of established SMEs: a systematic review of antecedents, outcomes and moderators", International Business Review, Vol. 25 No. 2 , pp. $458-470$.

Matzner, M., Büttgen, M., Demirkan, H., Spohrer, J., Alter, S., Fritzsche, A., Ng, I.C.L., Jonas, J.M., Martinez, V., Möslein, K.M. and Neely, A. (2018), "Digital transformation in service management", Journal of Service Management Research, Vol. 2 No. 2, pp. 2-21.

McCracken, G. (1988), “The long interview”, Qualitative Research Methods, Sage Publication, Newbury Park, Vol. 13.

Mikl, J., Herold, D.M., Ćwiklicki, M. and Kummer, S. (2020), "The impact of digital logistics start-ups on incumbent firms: a business model perspective", The International Journal of Logistics Management, Vol. 32 No. 4, pp. 1461-1480.

Miroshnychenko, I., Strobl, A., Matzler, K. and De Massis, A. (2021), "Absorptive capacity, strategic flexibility, and business model innovation: empirical evidence from Italian SMEs", Journal of Business Research, Vol. 130, pp. 670-682.

Murawska-Muthesius, K. and Piotrowski, P. (Eds) (2015), From Museum Critique to the Critical Museum, Ashgate Publishing, Farnham.

Mu.Sa (2017), "Museum of the future", available at: http://www.project-musa.eu/wp-content/uploads/ 2017/03/Museum-of-the-future-Italy_eng.pdf.

Musteen, M., Curran, R., Arroteia, N., Ripollés, M. and Blesa, A. (2018), "A community of practice approach to teaching international entrepreneurship”, Administrative Sciences, Vol. 8 No. 4, pp. 56-72.

Network of European Museums (NEMO) (2014), "Museums in the digital age. museums and the development of active citizenship", available at: https://www.ne-mo.org/fileadmin/Dateien/ public/statements_and_news/NEMO_21st_Annual_Conference_Documentation.pdf.

Network of European Museums (NEMO) (2020a), "Museums during COVID-19", available at: https:// www.ne-mo.org/advocacy/our-advocacy-work/museums-during-covid-19.html. 
Network of European Museums (NEMO) (2020b), "Survey on the impact of the COVID-19 situation on museums in Europe", Final Report, available at: https://www.ne-mo.org/fileadmin/Dateien/ public/NEMO_documents/NEMO_COVID19_Report_12.05.2020.pdf.

Network of European Museums (NEMO) (2020c), "The challenge that EU museums face to digitise their collections", available at: https:/www.digitalmeetsculture.net/article/the-challenges-thateu-museums-face-to-digitise-their-collections/.

Ng, I.C. and Wakenshaw, S.Y. (2017), "The internet-of-things: review and research directions", International Journal of Research in Marketing, Vol. 34 No. 1, pp. 3-21.

Oskam, I., Bossink, B. and de Man, A.P. (2018), "The interaction between network ties and business modeling: case studies of sustainability-oriented innovations", Journal of Cleaner Production, Vol. 177, pp. 555-566.

Osterwalder, A. and Pigneur, Y. (2010), Business Model Generation: A Handbook for Visionaries, Game Changers, and Challengers, Wiley, New York, NY.

Oughton, E., Frias, Z., Russell, T., Sicker, D. and Cleevely, D.D. (2018), "Towards 5G: scenario-based assessment of the future supply and demand for mobile telecommunications infrastructure", Technological Forecasting and Social Change, Vol. 133, pp. 141-155.

Parmentier, G. and Gandia, R. (2017), "Redesigning the business model: from one-sided to multi-sided", Journal of Business Strategy, Vol. 38 No. 2, pp. 52-61.

Patton, M.Q. (2002), "Two decades of developments in qualitative inquiry: a personal, experiential perspective", Qualitative Social Work, Vol. 1 No. 3, pp. 261-283.

Pencarelli, T., Conti, E. and Splendiani, S. (2017), "The experiential offering system of museums: evidence from Italy", Journal of Cultural Heritage Management and Sustainable Development, Vol. 7 No. 4, pp. 430-448.

Pisano, V., Ferrari, E.R. and Fasone, V. (2016), “The orchestration of business models for territorial development”, Measuring Business Excellence, Vol. 20 No. 4, pp. 72-83.

Porter, M.E. and Kramer, M.R. (2011), "Creating shared value”, in Lenssen, G. and Smith, N. (Eds), Managing Sustainable Business, Springer, Dordrecht, pp. 323-346.

Prem, E. (2015), “A digital transformation business model for innovation”, in Huizing, E., Conn, S., Torkkeli, M. and Bitran, I. (Eds), ISPIM Innovation Symposium, Singapore Management University, Singapore, pp. 123-133.

Raimo, N., De Turi, I., Ricciardelli, A. and Vitolla, F. (2021), "Digitalization in the cultural industry: evidence from Italian museums", International Journal of Entrepreneurial Behavior and Research.

Remane, G., Hanelt, A., Nickerson, R.C. and Kolbe, L.M. (2017), "Discovering digital business models in traditional industries", Journal of Business Strategy, Vol. 38 No. 2, pp. 41-51.

Ridder, H.G. (2017), "The theory contribution of case study research designs", Business Research, Vol. 10 No. 2, pp. 281-305.

Ruggieri, R., Savastano, M., Scalingi, A., Bala, D. and D’Ascenzo, F. (2018), "The impact of digital platforms on business models: an empirical investigation on innovative start-ups", Management and Marketing. Challenges for the Knowledge Society, Vol. 13 No. 4, pp. 1210-1225.

Russo-Spena, T. and Bifulco, F. (2021), Digital Transformation in the Cultural Heritage Sector, Springer International Publishing, Cham.

Russo-Spena, T., Tregua, M. and Bifulco, F. (2017), "Searching through the jungle of innovation conceptualizations: system, network and ecosystem domains", Journal of Service Theory and Practice, Vol. 27 No. 5, pp. 977-1005.

Russo-Spena, T., Tregua, M., D'Auria, A. and Bifulco, F. (2021), "Digital business models", in RussoSpena, T. and Bifulco, F. (Eds), Digital Transformation in the Cultural Heritage Sector. Challenges to Marketing in the New Era, Springher, pp. 39-68. 
IJEBR

28,8

2022

Schaltegger, S., Lüdeke-Freund, F. and Hansen, E.G. (2016), "Business models for sustainability: a coevolutionary analysis of sustainable entrepreneurship, innovation, and transformation", Organization and Environment, Vol. 29 No. 3, pp. 264-289.

Schiuma, G. and Lerro, A. (2017), "The business model prism: managing and innovating business models of arts and cultural organisations", Journal of Open Innovation: Technology, Market, and Complexity, Vol. 3 No. 3, pp. 13-25.

Shafer, S.M., Smith, H.J. and Linder, J.C. (2005), "The power of business models", Business Horizons, Vol. 48 No. 3, pp. 199-207.

Shaw, D.R. and Allen, T. (2018), "Studying innovation ecosystems using ecology theory", Technological Forecasting and Social Change, Vol. 136, pp. 88-102.

Sivarajah, U., Kamal, M.M., Irani, Z. and Weerakkody, V. (2017), "Critical analysis of Big Data challenges and analytical methods", Journal of Business Research, Vol. 70, pp. 263-286.

Sjödin, D., Parida, V., Palmié, M. and Wincent, J. (2021), "How AI capabilities enable business model innovation: scaling AI through co-evolutionary processes and feedback loops", Journal of Business Research, Vol. 134, pp. 574-587.

Stromberg, J. (2013), "What digitization will do for the future of museums", Smithsonian Magazine.

Teece, D.J. (2010), "Business models, business strategy and innovation”, Long Range Planning, Vol. 43 Nos 2-3, pp. 172-194.

Teece, D.J. (2018), "Business models and dynamic capabilities", Long Range Planning, Vol. 51 No. 1, pp. 40-49.

Teixeira de Melo, A. (2020), Performing Complexity: Building Foundations for the Practice of Complex Thinking, Springer, Cham.

Tesch, J.F. and Brillinger, A.S. (2019), "The evaluation aspect of digital business model innovation”, in Tesch, J. (Ed.), Business Model Innovation in the Era of the Internet of Things, Springer, Cham, pp. 67-86.

To, C.K., Au, J.S. and Kan, C.W. (2019), "Uncovering business model innovation contexts: a comparative analysis by fsQCA methods", Journal of Business Research, Vol. 101, pp. 783-796.

Tom Dieck, M.C. and Jung, T.H. (2017), "Value of augmented reality at cultural heritage sites: a stakeholder approach", Journal of Destination Marketing and Management, Vol. 6 No. 2, pp. 110-117.

Treem, J.W. and Leonardi, P.M. (2013), "Social media use in organizations: exploring the affordances of visibility, editability, persistence, and association", Annals of the International Communication Association, Vol. 36 No. 1, pp. 143-189.

Urbinati, A., Bogers, M., Chiesa, V. and Frattini, F. (2019), "Creating and capturing value from Big Data: a multiple-case study analysis of provider companies", Technovation, Vol. 84, pp. 21-36.

Vargo, S.L. and Lusch, R.F. (2017), "Service-dominant logic 2025”, International Journal of Research in Marketing, Vol. 34 No. 1, pp. 46-67.

Veit, D., Clemons, E., Benlian, A., Buxmann, P., Hess, T., Kundisch, D. and Spann, M. (2014), "Business models", Business and Information Systems Engineering, Vol. 6 No. 1, pp. 45-53.

Verhoef, P.C. and Bijmolt, T.H. (2019), "Marketing perspectives on digital business models: a framework and overview of the special issue", International Journal of Research in Marketing, Vol. 36 No. 3, pp. 341-349.

Verhoef, P.C., Kannan, P.K. and Inman, J.J. (2015), "From multi-channel retailing to omni-channel retailing: introduction to the special issue on multi-channel retailing", Journal of Retailing, Vol. 91 No. 2, pp. 174-181.

Wacker, J.G. (1998), “A definition of theory: research guidelines for different theory-building research methods in operations management", Journal of Operations Management, Vol. 16 No. 4, pp. 361-385. 
Weill, P. and Woerner, S.L. (2013), “Optimizing your digital business model”, MIT Sloan Management Review, Vol. 54 No. 3, p. 71.

Digital

business model

from cultural

heritage No. 4, p. 101892.

Zott, C. and Amit, R. (2010), "Business model design: an activity system perspective", Long Range Planning, Vol. 43 Nos 2-3, pp. 216-226.

Zott, C. and Amit, R. (2017), "Business model innovation: how to create value in a digital world", Marketing Intelligence Review, Vol. 9 No. 1, pp. 18-23.

Zott, C., Amit, R. and Massa, L. (2011), "The business model: recent developments and future research", Journal of Management, Vol. 37 No. 4, pp. 1019-1042.

\section{Corresponding author}

Tiziana Russo-Spena can be contacted at: russospe@unina.it

For instructions on how to order reprints of this article, please visit our website:

www.emeraldgrouppublishing.com/licensing/reprints.htm

Or contact us for further details: permissions@emeraldinsight.com 